Total Quality Management \& Business Excellence

\title{
How companies use the information about quality-related costs
}

\section{António Ramos Pires, Jorge Novas, Margarida Saraiva \& Aida Coelho}

To cite this article: António Ramos Pires, Jorge Novas, Margarida Saraiva \& Aida Coelho (2015): How companies use the information about quality-related costs, Total Quality Management \& Business Excellence, DOI: 10.1080/14783363.2015.1099427

To link to this article: http://dx.doi.org/10.1080/14783363.2015.1099427

册 Published online: 19 Oct 2015.

Submit your article to this journal

LII Article views: 17

Q View related articles

View Crossmark data $₫$ 
Total Quality Management, 2015

http://dx.doi.org/10.1080/14783363.2015.1099427

\title{
How companies use the information about quality-related costs
}

\author{
António Ramos Pires ${ }^{\mathrm{a} *}$, Jorge Novas ${ }^{\mathrm{b}}$, Margarida Saraiva ${ }^{\mathrm{c}, \mathrm{d}}$ and Aida Coelho ${ }^{\mathrm{e}}$ \\ ${ }^{a}$ Polytechnic Institute of Setúbal, Setúbal, Portugal; ${ }^{b}$ Management Department, CEFAGE-UE, \\ University of Évora, Évora, Portugal; ${ }^{c}$ Management Department, University of Évora, Évora, \\ Portugal; ${ }^{d}$ BRU-UNIDE/ISCTE-IUL, Lisbon, Portugal; ${ }^{e}$ Polytechnic Institute of Santarém, \\ Santarém, Portugal
}

\begin{abstract}
This work focuses on the broad topic of quality-related costs (QRC), which has been largely discussed in the literature. Nevertheless, one of the least studied issues relates to the way companies use QRC information. In this research the profile of use of QRC information is analysed considering the model proposed by Simons [(1991). Strategic orientation and top management attention to control systems. Strategic Management Journal, 12(1), 49-62], from which it is possible to distinguish between a diagnostic and an interactive profile of use. The analysis of the data collected through a questionnaire survey to a sample of Portuguese certified companies (PCCs) involved the application of principal component analysis, cluster analysis, one-way analysis of variance and discriminant analysis. The results showed that a substantial part of PCCs use the QRC information according to a diagnostic and interactive profile. Managers of these companies use QRC information to set goals, monitor their implementation and motivate participants (according to a diagnostic profile), but also to foster organisational learning, the emergence of new ideas and strategies (according to an interactive profile). About $30 \%$ of companies favour a diagnostic profile. However, about 32\% of companies report negative values for both profiles, indicating that these companies undertake initiatives to prepare QRC information but their leaders do not use it in the management process.
\end{abstract}

Keywords: quality-related costs; interactive and diagnostic systems; profiles of use of information; information to management

\section{Introduction}

Throughout the 1980s, organisations started to incorporate quality principles into their management systems in the scope of a broader view of Total Quality Management (TQM) (Weinstein, Vokurka, \& Graman, 2009). Literature proposes a set of definitions for the concept of TQM. Despite this, there seems to be a common idea that TQM is an organisational approach to ensure the desired quality levels in an efficient way through the involvement of all members of the organisation (see Oakland, 1989; Smith, 2005). According to Kanji (1990), Quality refers to the continued satisfaction of the customer needs (internal and external), Total Quality refers to the attainment of quality with reduced costs and TQM refers to the attainment of total quality through the permanent commitment of all members of the organisation.

Any serious attempt to improve quality must address the costs related to the attainment of quality, as the purpose of continuous improvement programmes is not only to meet customers' demands, but also do so at the lowest cost. This may be achieved through an action on costs, seeking their reduction, for what it is necessary for their identification and measurement (Schiffauerova \& Thomson, 2006). The process of identification and measurement of

*Corresponding author. Email: antonio.pires@estsetubal.ips.pt 